\title{
5
}

\section{The Changed Architecture of the EU's Agricultural Policy Over Four Decades: Trade Policy Implications for Australia}

\author{
Alan Swinbank and Carsten Daugbjerg
}

When the European Economic Community (EEC)—today's European Union (EU) — created its common agricultural policy (CAP) in the 1960s and 1970s it paid scant regard to the interests of other nations. That 'old' CAP attempted to increase farm incomes by manipulating farm-gate prices, while a nascent, but rather ineffectual, structural policy sought to improve the competitive structure of European agriculture. Details differed from one product to another, but market price support meant in the main that imports were heavily taxed, exports subsidised and intervention stocks accumulated. When, in 1973, the EEC was enlarged with the accession of Denmark, Ireland and the United Kingdom (UK) — the latter a major importer of agricultural products from world markets-trade diversion was inevitable, and Australia in particular found its agricultural products displaced from the UK market. The CAP's escalating budgetary costs in the 1980s led to some half-hearted attempts at reform, but it was the Uruguay Round of trade negotiations under the auspices of the General Agreement on Tariffs and Trade (GATT) that triggered a succession of 'reforms' that significantly changed the CAP's policy mechanisms, while retaining its core focus of farm income support (Daugbjerg \& Swinbank 2009, 2011, 2016). The latest recalibration 
of the CAP, in 2013, established the policy framework for the period 2014-20. The aim of this chapter is to briefly explain the succession of policy changes of the last four decades and how it has changed the policy context within which a free trade area agreement with Australia has to be considered.

\title{
Accession of the UK to the CAP of the 1970s
}

By the time of the UK's accession to the EEC in 1973, the main outlines of the old-style CAP were firmly in place (see Box 1; and Harris, Swinbank \& Wilkinson 1983). In the late 1960s, the then European Commissioner for Agriculture, Sicco Mansholt, had attempted a CAP reform, arguing that support prices were too high, and that significant structural change, and investment, was needed to improve the competitive position of European agriculture; but his efforts were rebuffed and for his pains he was dubbed the 'peasant killer' ('Bauernkiller') amid angry street protests (Merriënboer 2011: 511-8). All that was achieved was the adoption in 1972 of three rather ineffectual 'structural directives', which had the objective of improving the efficiency of European agriculture (Harris, Swinbank \& Wilkinson 1983: 222-4).

\begin{abstract}
Box 1. The terminology of price support
The language differed from product to product, and has subsequently varied over time, but in the cereals regime, for example, the EEC's institutions fixed an intervention price-at which the member states would purchase grain to add to intervention stocks. To stop cheaper imports from undercutting the higher EEC market price, at the border a threshold price was fixed, and a variable import levy was payable on imports to bridge the gap between the lower world market price and this threshold price. As the EEC's level of self-sufficiency increased, exports became necessary if intervention stocks were not to continue increasing; but private traders would only export if they were paid subsidies to do so. Thus, export refunds were required. The costs of intervention, and export subsidies, were borne by the EEC's budget. In 1995 the Uruguay Round's Agreement on Agriculture placed a cap on subsidised exports, limited the extent to which domestic market prices could be supported, and through a process referred to as tariffication converted most border measures, such as variable import levies, into fixed tariffs, which were then reduced (Daugbjerg \& Swinbank 2009: 54).
\end{abstract}

The world food crisis of the early 1970s, together with the opening of the UK's food market for surpluses from the European continent, meant that any internal constraints on generous increases in support prices in the annual farm price review could, for the moment, be ignored. The Dillon (1960-62), Kennedy (1964-67) and Tokyo (1973-79) Rounds of multilateral trade negotiations in the GATT had little impact 
on the CAP, as did attempts by the United States of America (USA), Australia and others to challenge aspects of the CAP through GATT's dispute settlement procedures (Daugbjerg \& Swinbank 2009: 76-80). Academics had criticised the CAP, and suggested alternative approaches (e.g. Corbet \& van Riemsdijk 1973), but their comments were largely ignored. Consumer interests and, at the time, the environmental lobby had very little influence over the design of EEC farm policy; but with lower world market prices, and the increase in EEC production outpacing consumption, by the early 1980s the budget cost was beginning to bite (Moyer \& Josling 1990: 24-7).

The frustrations felt by Australia at the time were forcibly expressed by Australia's Minister for Special Trade Representations in the House of Representatives in March 1978. He declared that trade was 'causing great strains between Australia and the EEC'. A major problem was the CAP:

We are efficient producers of agricultural products ... Yet the EEC is denying us the opportunity, the right, to compete in its markets. Worse, the EEC is disposing of the surpluses caused by its policies at heavily subsidised prices on third markets in which we would otherwise sell our products (Garland 1978).

In particular, he claimed that 'Australia is the country worst affected by the enlargement of the EEC and its common agricultural policy'. He asserted that exports of beef had been badly affected 'as a result of the imposition of increasingly protective mechanisms', and that the 'application of the EEC's common agricultural policy to United Kingdom imports has wiped out our trade in sugar and butter to the EEC' (Garland 1978). The Australian Government commissioned its own research to demonstrate the follies of the CAP (e.g. Bureau of Agricultural Economics 1985) for presentation at workshops in Europe.

\section{A brief history of CAP reform}

The CAP of the mid-2010s is significantly different from the 'old' CAP of the 1970s and '80s, as described above. In particular, it can be claimed with some justification that it is much less trade distorting, that the costs it imposes on European consumers (and the economy as a whole) are much reduced, and that more care is taken to ensure that its environmental impact is benign. This section outlines the policy changes that have brought this about, while highlighting the international trade dimension. 
Budget pressure in the 1980 s prompted the first policy changes. In 1984, milk quotas were introduced to curb the upward trend in milk production, much of which was surplus to the EU's requirements and had been converted into butter and skim milk powder for sale to intervention. Although a temporary measure, milk quotas lasted until 2015. Then in 1988 , with the budgetary costs of the CAP still increasing, partly because of the need to subsidise a growing surplus of cereals, a new system of agricultural stabilisers was introduced. Limits were placed on the growth in the CAP budget—although no policy mechanisms would be directly triggered if the limit was breached-and for key commodities such as cereals the intent was that automatic reductions in support prices would apply if production exceeded a maximum guaranteed quantity (Swinbank \& Tanner 1996: 85-6).

The changes introduced in 1992 were far more significant. Although prompted in part by a continuing budget crisis, in reality the major problem that the EU had to address was the stalemate over agriculture in the Uruguay Round negotiations. The Uruguay Round had been launched in 1986 as a single undertaking, in which nothing was agreed until everything was agreed. The USA had demanded sweeping changes in the rules governing farm support, with the Australian-led Cairns Group playing a mediating role (Kenyon \& Lee 2006).

The EU had been reluctant to make significant concessions on agriculture, but in the lead-up to the ministerial meeting at the Heysel conference centre in Brussels in December 1990-initially arranged to ceremonially close the Round-it became obvious that the EU would have to reform its CAP if it were to achieve its wider ambitions for the Uruguay Round. Following the breakdown of the Heysel ministerial meeting, the European Commissioner for Agriculture, Ray MacSharry, launched his CAP reform plan. Agreement was secured in May 1992 with the Portuguese farm minister, Arlindo Cunha, chairing the Council of Agricultural Ministers. As Cunha has noted, 'after the Heysel deadlock, GATT negotiations and CAP reform were inevitably linked, despite the politically correct official line of denying such a link in public' (Cunha \& Swinbank 2011: 82).

The MacSharry reform began the decoupling of support for European farmers. The core agreement concerned cereals. Here support prices were cut by a third. Furthermore, they were fixed in nominal terms for an indefinite period: no longer would an annual price review result in inflationary increases in intervention prices. To compensate farmers for the implied loss in revenue they could claim an arable area payment. 
Thus, the incentive to increase yields, or even harvest the crop, was lessened. The per hectare payment was based on a regionally determined historic yield, multiplied by the reduction in support prices. Larger farm businesses had to set aside (i.e. not use) 15 per cent of their arable area, although the arable area payment was still payable on the land set aside (Swinbank \& Tanner 1996: 94-5). The oilseed, beef and sheep meat regimes were also amended, and provisions for support for environmental policies were introduced.

A critical juncture in the two negotiations came in the spring of 1992 when it became clear that the USA would accept the concept of a blue box of domestic support into which the area and livestock payments being negotiated in the CAP reform could be slotted (Cuhna \& Swinbank 2011: 83). ${ }^{1}$ This encouraged ministers to press ahead with CAP reform, which was an important step in enabling the Uruguay Round negotiations on agriculture to be concluded satisfactorily. Thus, not only did the Uruguay Round negotiations put pressure on the EU to reform its agricultural policy (Kenyon \& Lee 2006), but as Tanner (1996: 31) has pointed out, within the Uruguay Round's 'consensus framework, the pace of change [was] determined by the extent to which the most recalcitrant participant [was] prepared to proceed'. Thus, 'the imprint of the European Union's domestic reforms [was] clearly stamped on the final agricultural outcome'.

Moreover, as Tangermann (2004: 40) highlighted, the Uruguay Round 'also affected the nature of the policy debate in agriculture. The WTO has become a relevant factor in agricultural policy making'. Thus, it was in the Agenda 2000 reform of 1999, and the Fischler reforms of 2003-04, that the EU sought to anticipate the likely future outcome of trade negotiations in what was now the World Trade Organization (WTO), and was obliged to make changes to its sugar policy to bring its sugar exports into conformity with a ruling from the WTO's Dispute Settlement Body in a case brought by Australia, Brazil and Thailand (Daugbjerg \& Swinbank 2009: 114-5).

\footnotetext{
1 For developed economies the final agreement made provision for three categories of domestic support. Support deemed to be decoupled, with 'no, or at most minimal, trade-distorting effects or effects on production', and as defined in Annex 2 to the Agreement on Agriculture (the green $b o x$ ), would not be subject to reduction commitments. Blue box measures-direct payments under production-limiting programmes-such as the EU's area and livestock payments, were also exempt from reduction commitments. All other 'domestic support measures in favour of agricultural producers' - the amber box - would, after a transitional period, be limited to 80 per cent of the support granted in a historic base period (Daugbjerg \& Swinbank 2009: 54).
} 
The Agenda 2000 CAP reform was negotiated in the run-up to the WTO ministerial meeting in Seattle, at which it was thought a Millennium Round of trade negotiations might be launched. The EU at the time was of the view that any agreement on agriculture in a Millennium Round could be limited to a further tranche of reductions (to import tariffs, domestic support and export subsidies) similar to those agreed in the Uruguay Round. But the EU was worried about its ability to abide by the existing export subsidy limits on cereals. It was also keen to appeal to the Uruguay Round agreement's reference to the need to respect the non-trade concerns of WTO members, particularly the multifunctionality of European agriculture (Daugbjerg \& Swinbank 2009: 157-9).

The Agenda 2000 package was also concerned with establishing a new Financial Framework for the 2000-06 planning period, a reform of the structural funds, and preparation for enlargement to embrace up to 10 former communist regimes from Central and Eastern Europe (Cunha \& Swinbank 2011: 107).

With regard to the CAP market price regimes, Agenda 2000 resulted in a further decoupling of farm support. This involved another cut in support prices for cereals and beef, and one for butter and skim milk powder to apply from 2005, with partially offsetting increases in area and livestock payments, and a new blue box payment for milk producers. Support for environmental enhancement on farms, investment in restructuring European agriculture, and a new dimension of rural development were packaged together as the second pillar of the CAP, although the budget devoted to the second pillar remained small in relation to first pillar expenditure on market price support and direct payments. In a further effort to enhance the CAP's green credentials, member states had the option of introducing cross-compliance, making full disbursement of area and livestock payments conditional upon the farmer having complied with a number of environmental conditions. But few did. Although the package covered the period until 2006, a little noticed provision provided for a mid-term review in the early 2000s.

In his second term as European Commissioner for Agriculture and Rural Development, Franz Fischler took the opportunity of turning this midterm review into another substantial reform of the CAP in 2003 and 2004: the Fischler reform. This resulted in more decoupling of support, in two respects. First, all the direct payments that had been introduced by the MacSharry and Agenda 2000 reforms, but that were still linked to areas 
planted or the number of livestock kept, were transferred into the new single payment scheme. Although farmers had to have agricultural land at their disposal on which to claim their entitlement, and this land had to be kept in good agricultural and environmental condition and other crosscompliance conditions respected, in the main the link with production was broken. For example, ex-dairy farmers could continue to claim a payment in compensation for the cuts in milk support, but they no longer had to keep cows, and could instead engage in other agricultural activities. Second, in 2004 and subsequent years, the decoupled single payment scheme was extended to other products that had not been touched by the MacSharry and Agenda 2000 reforms, such as olive oil, processed fruit and vegetables, and hops (Swinbank \& Daugbjerg 2006).

Although some member states engaged in the full-decoupling allowed under the single payment scheme, others opted for only partial decoupling. For example, member states had the option to link 25 per cent of the displaced area payment for cereals to continued planting of a cereal crop. Most of these residual partial decoupling options were, however, removed by the Health Check of 2008 (Daugbjerg \& Swinbank 2011).

At the outset of the Doha Round in 2001 the EU had been on the defensive, still seeking to defend the CAP and limit the impact of any new agreement on agriculture. But CAP reform and WTO negotiations interacted, and the Fischler reform allowed the EU to adopt a more proactive stance. Franz Fischler claimed, after the reform package had been agreed in June 2003, that:

Today marks the beginning of a new era. European agricultural policy will change fundamentally. In future, our products will be more competitive, and our agricultural policy will be greener, more trade-friendly and more consumer-oriented. ...

The reform's message to the world is clear: today we have largely said goodbye to an old system of support which distorted trade. The new agricultural policy is trade-friendly, particularly as regards its effects on developing countries.

This will put us on the offensive at the WTO negotiations in Cancún in September (Fischler 2003).

The WTO ministerial meeting in Cancún in September 2003, however, failed to conclude the Doha Round. 


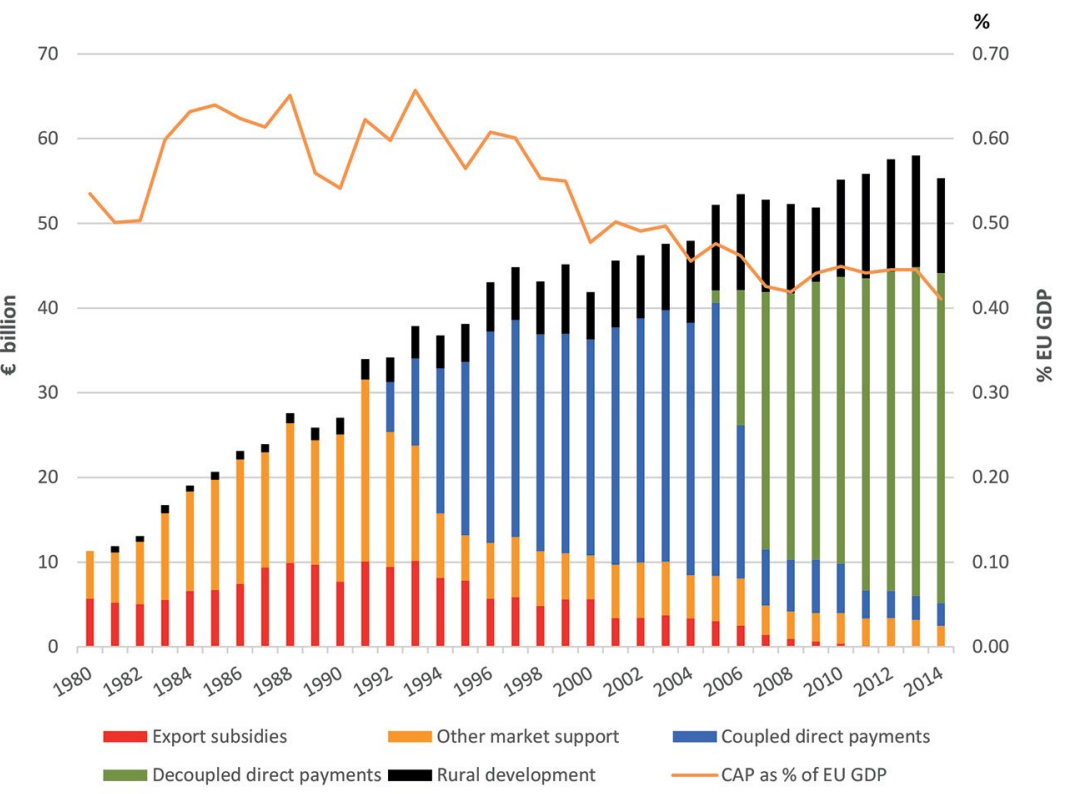

Figure 1. EU budget expenditure on the CAP, 1980-2014, in $€$ billion and as a percentage of EU GDP, current prices

Source: Data compiled and supplied by the EU's Directorate General for Agriculture and Rural Development.

Figure 1 shows the evolution of EU budget expenditure on the CAP from 1980 to 2014, through the MacSharry, Agenda 2000, Fischler and Health Check reforms, and as it enlarged from nine to 28 member states. For the last decade the level of expenditure has been more or less constant in nominal terms (and thus has declined in real terms), while falling as a percentage of the EU's gross domestic product (GDP). In the 1980s, under the 'old' CAP, expenditure on market support (e.g. intervention) and export subsidies dominated, and the 'rural development' budget was poorly developed.

The 1992 MacSharry reform (and Agenda 2000) reduced expenditure on the area labelled 'other market support' in Figure 1, with an offsetting increase in coupled direct payments. In the WTO, these area and livestock payments were declared as blue box measures, with a corresponding decrease in amber box support. Then the Fischler reforms of 2003-04, and subsequent changes, switched most of the coupled direct payments, and some expenditure on market support, into the decoupled single payment scheme-labelled 'decoupled direct payments' in Figure 1. These were declared as green box expenditure in the WTO. 
Another notable development was the decrease in the use of export subsidies. In the early 1980s, half of the EU agricultural budget was spent on export subsidies while they only accounted for a small fraction in the late 2000s. This development was partly a result of the MacSharry and Agenda 2000 reforms, which lowered internal support prices. With a smaller price difference between EU internal and world market prices, less subsidisation was needed to compensate exporters for the price difference. Improved world market prices further contributed to the decrease in the use of export subsidies.

Thus by 2010 export subsidies were largely a matter of the past. Indeed, the EU had already agreed to ban their use in the context of an overall agreement to the Doha Round. Then, at the Ministerial Conference in Nairobi in December 2015, it was decided that 'Developed Members' would eliminate their remaining export subsidy entitlements for most products with immediate effect, with the remainder to go by the end of 2020 (WTO 2015: paragraph 6). Australia, however, continues to monitor the export of sugar from the EU (Swinbank 2015), and is entitled to do so until the EU's quota regime for sugar expires in 2017.

Although some analysts have queried how decoupled the EU's policies really are, particularly in the aggregate, the declarations of domestic support to the WTO have not been seriously challenged. The numbers suggest that the decoupling of the CAP over the period 1992 to 2008 meant that no further changes would be required to meet the stricter limits on domestic support that were envisaged in the Revised Draft Modalities for Agriculture circulated in 2008 (Swinbank 2015; WTO 2008).

What these policy reforms have not done, however, is change the EU's protective tariff regime. Tariffs remain at the levels established in the Uruguay Round, and it is unlikely that the EU will agree to reductions except in the context of a multilateral agreement in the WTO (although temporary suspensions have applied in response to high market prices). Thus, for example, the most-favoured-nation (MFN) tariff on white sugar remains at $€ 419$ per tonne despite the fact that the 2006 sugar reform reduced the support price from $€ 631.9$ to $€ 404.4$ per tonne (Noble 2012: 12-13). High tariffs have a particular significance when considering free trade areas, such as that being considered between Australia and the EU; this is discussed below. 


\section{Multifunctionality}

In the run-up to the Seattle ministerial meeting, the EU and its allies ('the friends of multifunctionality') were keen to stress that in the densely populated Old World the use of agricultural land had a wider social and environmental dimension than the simple provision of agricultural products. Thus, European agriculture sustained a diverse fauna and flora, a treasured landscape, cultural diversity, and so on. Furthermore, if these alleged public goods were to be produced in the future, then the farm sector had to be protected, or else overseas producers who were not expected to meet the same environmental norms (those located in the New World in particular) could flood the European market with lower-cost produce, and Europe's multifunctional agriculture would be threatened. Although the European Commission soon desisted from using the term 'multifunctionality' in Geneva, because of the adverse reaction of its trading partners, the basic idea still pervades much European thinking about agriculture.

Critics suggest that the public goods associated with the concept of multifunctionality could be delivered on the basis of a series of contracts between the EU and individual farmers. Thus, for example, Anderson (2000: 491) concluded that the WTO's green box provisions 'are adequate for dealing with the main issues raised'. However, there is a trade-off between the administrative costs of negotiating, and monitoring, tens of thousands of contracts with individual land managers for the delivery of environmental services, and a more generic approach in which the expectation is that land managers will produce a multifunctional agriculture although, in strictly contractual terms, not required to do so. In the 2013 recalibration of the CAP, and the so-called greening of direct payments, this broad-brushed approach prevailed, as discussed below.

\section{The single market and its regulatory provisions}

Although a number of regulatory provisions relating to European agriculture are governed by national rules - taxation of farm business profits, landlord-tenant relations, land zoning and planning laws, for example-the opposite is the case for legislation that might affect the free movement of goods within the EU's single market. Thus, geographical indications of origin, wine denominations, food law, plant health and veterinary rules are either regulated by EU legislation, or the principle of mutual recognition that guarantees the free movement of goods between 
member states provided fundamental public safety provisions are not compromised. One prominent domain in which this basic single-market concept is potentially threatened relates to the use of genetically modified products in animal feed and human food (Agra Facts 2015).

The concept of a single market is very important to EU policy makers, and it extends beyond the territorial domain of the EU. Countries such as Norway that are not members of the EU, but are members of the European Economic Area (in essence a 'GATT-plus' FTA), have to apply the EU's single-market regulatory provisions just as they would were they EU member states. Similarly, as the EU has extended its web of FTAs around the world, so it has attempted to extend its regulatory regimes, particularly geographical indications, to its FTA partners (Kerr \& Hobbs 2015).

\section{The post-2013 CAP}

The 2003 (Fischler) and 2008 (Health Check) reforms had not been linked to the determination of the periodic financial frameworks that the EU had been operating for two decades, but it was agreed that the CAP budget (and thus the CAP itself) would be reviewed in establishing the 2014-20 financial framework. That review was concluded under the second College of Commissioners headed by José Manuel Barroso, with Dacian Cioloş serving as European Commissioner for Agriculture and Rural Development.

Circumstances had changed. One consequence of the price gyrations experienced on world commodity markets since the mid-2000s was that a number of EU governments and members of the European Parliament were extremely wary of a neo-liberal approach to agricultural policy, canvassed for a 'strong' CAP, and expressed concerns about food security. The near collapse of the world financial system following the Lehman Brothers debacle of 2008, the sovereign debt crisis and austerity budgets experienced by many EU member states, and the stark suggestion that one or more countries might have to abandon their use of the euro, suggested to others that the CAP budget should be reduced to reflect the straightened circumstances of the time: if social welfare programs were being cut why should CAP income support be spared? 
Following ratification of the Lisbon Treaty, the European Parliament had enhanced decision-making powers over the CAP-it had become the co-legislator with the Council of Ministers-boosting the power of the European Parliament's Committee on Agriculture and Rural Development (COMAGRI). Moreover, the new member states that had acceded in 2004 and 2007 were expressing more forcibly their criticism of a system of farm income support that they believed disadvantaged their farmers in favouring those in most of the old member states. And the Doha talks remained in deep freeze.

The recalibrated CAP that emerged after an extended negotiation is, in its broad outlines, not hugely different from its pre-2013 predecessor, but the detail is exceedingly complex (despite the declared objective of simplification!), and member states have considerable discretion in how they apply important provisions.

The trade regime is unaltered. As in previous reforms the EU's import tariffs have not been touched, and legislation would still have allowed the use of export subsidies. The residual elements of domestic market price support have not, in substance, been changed; although milk quotas were abolished in 2015 and sugar quotas will go in 2017, both of which may affect the EU's net trade balance.

The European Commission proposed a CAP budget for 2014-20 more or less unchanged from 2013 in nominal terms, although declining in real terms, and this was accepted with some modification by the colegislators. It is widely believed that Commissioner Cioloş had argued in the College of Commissioners that a substantial budget was needed to enable the CAP to face the challenges of climate change. Whether the outcome of the reform matched that expectation is not explored here. Despite the environmental and greening rhetoric, there was no marked switch in the budget from Pillar 1 (market price and income support) to Pillar 2 (rural development), but in drawing up their rural development plans member states have had to pay more attention to promoting a lowcarbon and climate-resilient economy.

On direct payments (the successor to the previous single payment scheme) there are a number of changes, three of which are highlighted here. First, most noticed in the media was the decision to devote 30 per cent of the direct payments budget to a new greening component. What is now known as the basic payment will be claimed and paid annually as under the old single payment scheme: farm businesses have to have enough 
agricultural land at their disposal to match, hectare by hectare, their basic payment entitlements, and cross-compliance means that a number of environmental, food safety, and animal welfare provisions must be observed if payments are to be received in full. In addition, to claim the greening component on their land a series of requirements will apply, outlawing, for example, mono-cropping on larger arable farms.

Whether these measures in a cost-effective way will help retain soil carbon and combat global warming, and enhance environmental provision, are questions under debate in Europe. The European Commission offered little evidence to support its contention that greening would achieve significant environmental benefits, and the Council of Agricultural Ministers and the European Parliament significantly watered down the Commission's initial intent in legislating for the post-2013 CAP (Hart 2015). The green box status in the WTO of these greening payments might also be queried (Swinbank 2015).

Second, in addition to the need to meet the new greening requirements, some of Europe's farmers will find that the level of their payments changes significantly. There is a limited redistribution of funds between member states, boosting payments, for example, in the Baltic States where payments were seen to be significantly below the EU norm. Elsewhere, if member states had not already moved to a flat-rate per hectare payment on a regional basis, they will now be obliged to do so. Farmers who, for a variety of reasons, had accumulated large payment entitlements on their farms may now see their payments decline to the regional average, while others gain.

Third, member states now have a variety of options to recouple part of the basic payment to specific production activities; known as voluntary coupled support (Daugbjerg \& Swinbank 2016). Some member states have announced that they will make little use of this provision; others plan to do so to the maximum extent permitted. Overall, the European Commission (2015: slide 19) believes that 10 per cent of the direct aid budget will now be coupled-more than was the case in the pre-2013 CAP, but less than was allowed following the 2003 reform. The change will not jeopardise the EU's ability to meet its current domestic support commitments in the WTO, but international observers might have noted that the French farm minister referred to 'an historic turning-point that breaks with the process of decoupling aid that has prevailed since 1992' (Embassy of France 2013). 


\section{Free trade area agreements and the CAP}

The EU is proud of its achievements in liberalising the import of agricultural products from selected developing countries. Thus, under its Everything but Arms (EBA) initiative it offers duty- and quota-free access for products originating in the least developed countries (LDCs), and it is party to a series of free trade area agreements-known as Economic Partnership Agreements (EPAs) - with African, Caribbean and Pacific Group of States (ACP) countries (Daugbjerg \& Swinbank 2009: 162-3). Both allow for the free importation of white sugar, and raw cane sugar for refining, for example. Agreements with states around the Mediterranean Basin give access for fruit and vegetables, olive oil and other Mediterranean products.

Given the failure to progress the Doha Round, attention has refocused on bilateral trade deals-FTAs - with non-LDC and non-ACP developing countries in Asia and South America, and with developed economies such as Australia, Canada and the USA. Negotiations on a Comprehensive Economic and Trade Agreement (CETA) with Canada, for example, began in 2009 (Kerr \& Hobbs 2015: 437), but the European Parliament's approval was only secured in February 2017.

When countries form an FTA they are supposed to ensure that 'duties and other restrictive regulations of commerce ... are eliminated on substantially all the trade between the constituent territories in products originating in such territories' (GATT Article XXIV: 8, emphasis added). Despite an attempt in the Uruguay Round to clarify what 'substantially all the trade' meant, it remains an unclear, and untested, provision. It seems doubtful, however, that an entire sector such as agriculture could be excluded, as had been the case prior to 1995. As the Commission of the European Communities (1995: 4) commented at the time: 'To date, the free trade agreements concluded by the Union have been restricted in terms of product coverage. In particular, they have generally excluded all or most agricultural trade'. With exceedingly high import tariffs on, for example, sugar, beef and dairy products, and the 'old' CAP's support arrangements designed to keep EU prices well in excess of those prevailing on world markets, it was indeed difficult to see how the EU's protected agricultural sector could be included in an FTA with a competitive agricultural exporter. 
Despite the changes to the CAP over the last two decades-the MacSharry, Fischler and other reforms - the tariffs on many agricultural products remain stubbornly high. Thus, a competitive supplier of sugar or beef, for example, might aspire to the inclusion of these products in an FTA with the EU, while EU producers can be expected to object. If one competitive supplier gains entrée in this way, others will want to negotiate (or renegotiate) their own FTAs to gain comparable access to the EU's protected market: precedents do matter. Thus, as Kerr and Hobbs (2015) document, 'sensitive' agricultural products tend to be excluded from the draft Canada-EU CETA, or-like European cheeses into the protected Canadian market, or Canadian beef (but hormone free) into the EU-are granted restricted access based on tariff rate quotas. As Commissioner Cioloş (2014) acknowledged, 'the EU capacity to absorb additional concessions in the beef sector is limited ... The composition and size of tariff quotas are most relevant in this respect'. Moreover, he noted:

[b]eef was one of the most important elements for Canada in this negotiation, and this concession should be seen as part of a wider agricultural package: The EU obtained results on its offensive interests in agriculture including protection of Geographical Indications and very significantly improved market access for key products including dairy.

The willingness of the EU to open its market for increased beef imports—a politically sensitive issue-may indicate that agriculture is not a deal-breaker to the extent that it was in the past. Nonetheless, Kerr and Hobbs (2015: 454) conclude, perhaps overly pessimistically: 'The subsectors of agriculture in each market that were heavily protected prior to the CETA remain heavily protected at the conclusion of the negotiations. No areas of substantial liberalisation in agri-food trade are included in the text of the CETA'. Whether Australia could do better remains an open question.

In 1973, Australia's agricultural exports were adversely affected by the UK's accession to the then EEC. The world has moved on, and agricultural markets are significantly different now to what they were then. The CAP has changed, but many of the EU's agri-food sectors are still protected by prohibitively high MFN tariffs. An FTA with the EU that incorporates these products in a meaningful way is an outcome to be prized by a competitive agricultural exporter, even if it means incorporating some of the EU's regulatory measures, such as recognition of the EU's geographical indications, into the free trade area agreement. 
The result of the UK's June 2016 referendum on EU membership, and the government's subsequent decision to trigger the withdrawal process ('Brexit'), could well mean that the UK will have left the EU by the end of March 2019 (Swinbank 2017). Is it an FTA with the remainder of the EU that the Australian farm sector would want to secure, one with the UK, or perhaps with both?

\section{Concluding comments}

This chapter has acknowledged that the 'old' CAP of the 1970s was highly protectionist, causing significant distortions to world trade, particularly for efficient agricultural exporters such as Australia. However, it has also sought to show that the policy has changed significantly, and that its distortions to international trade are much reduced (although there has been no attempt here to demonstrate this empirically). A number of pressures have borne down on EU policy makers that help explain this policy shift, but international pressure exerted through the GATT/WTO has - the authors believe- been crucial. This is why we deplore the failure to conclude the Doha Round, which would have the effect of locking in past CAP reforms. Despite the policy changes, the high tariffs on agrifood products established by the EU at the conclusion of the Uruguay Round remain in place-another reason to deplore the international community's failure to conclude the Doha Round. But this does mean that an FTA with the EU that effectively sidesteps these trade barriers is potentially important for an efficient agricultural exporter.

\section{References}

Agra Facts (2015), 'Commission Tables Plan Allowing Countries to Ban Use of GM Animal Feed', Agra Facts No. 31-15, 22 April: 1.

Anderson, Kym (2000), 'Agriculture's "multifunctionality" and the WTO', Australian Journal of Agricultural and Resource Economics 44(3): 475-94. doi.org/10.1111/1467-8489.00121.

Bureau of Agricultural Economics (1985), Agricultural Policies in the European Community: Their Origins, Nature and Effects on Production and Trade, Policy Monograph No. 2 (Australian Government Publishing Service: Canberra). 
Cioloş, Dacian (2014), Answer given by Mr Cioloş on behalf of the Commission, 18 September, Written Question E-006196-14, European Parliament. Available at www.europarl.europa.eu/sides/getAll Answers.do?reference $=E-2014-006196 \&$ language $=E N$, last accessed 3 June 2015.

Commission of the European Communities (1995), Free Trade Areas: An Appraisal, SEC(95)322 (Commission of the European Communities: Brussels).

Corbet, Hugh \& J. F. van Riemsdijk (eds) (1973), 'Wageningen memorandum on the reform of the European Community's Common Agricultural Policy', European Review of Agricultural Economics 1(2): 151-60. doi.org/10.1093/erae/1.2.151.

Cunha, Arlindo with Alan Swinbank (2011), An Inside View of the CAP Reform Process: Explaining the MacSharry, Agenda 2000, and Fischler Reforms (Oxford University Press: Oxford).

Daugbjerg, Carsten \& Alan Swinbank (2009), Ideas, Institutions, and Trade: The WTO and the Curious Role of EU Farm Policy in Trade Liberalization (Oxford University Press: Oxford). doi.org/10.1093/ acprof:oso/9780199557752.001.0001.

Daugbjerg, Carsten \& Alan Swinbank (2011), 'Explaining the "health check" of the Common Agricultural Policy: Budgetary politics, globalisation and paradigm change revisited', Policy Studies 32(2): 127-41. doi.org/10.1080/01442872.2010.541768.

Daugbjerg, Carsten \& Alan Swinbank (2016), 'Three Decades of Policy Layering and Politically Sustainable Reform in the European Union's Agricultural Policy', Governance 29(2): 265-280. doi.org/10.1111/ gove.12171.

Embassy of France in Washington (2013), 'CAP reform. Communiqué issued by the Ministry of Agriculture, the Food Industry and Forestry. Paris, March 26, 2013'. Available at ambafrance-us.org/spip. php?article4468, last accessed 19 September 2013.

European Commission (2015), The CAP towards 2020. Implementation of the New System of Direct Payments. MS Notifications (European Commission: Brussels). 
Fischler, Franz (2003), 'The New, Reformed Agricultural Policy', Final Press Conference After the Decision at the Council on Agriculture, Luxembourg, 26 June, Speech/03/326 (Commission of the European Communities: Brussels).

Garland, (Ransley) Victor (1978), 'Australia's Trade Relations with the European Economic Community. Ministerial Statement', Thursday, 16 March (House of Representatives: Canberra).

Harris, Simon, Alan Swinbank \& Guy Wilkinson (1983), The Food and Farm Policies of the European Community (John Wiley \& Sons: Chichester).

Hart, Kaley (2015), 'The fate of Green Direct Payments in the CAP Reform negotiations' in Johan Swinnen (ed.), The Political Economy of the 2014-2020 Common Agricultural Policy: An Imperfect Storm (Rowman \& Littlefield International: London), 245-76.

Kenyon, Don \& David Lee (2006), The Struggle for Trade Liberalisation in Agriculture: Australia and the Cairns Group in the Uruguay Round, The Foreign Affairs and Trade Files No. 4 (Department of Foreign Affairs and Trade: Canberra).

Kerr, William A. \& Jill E. Hobbs (2015), 'A protectionist bargain?: Agriculture in the European Union-Canada Trade Agreement', Journal of World Trade 49(3): 437-56.

Merriënboer, Johan van (2011), Mansholt: A Biography (P.I.E. Peter Lang: Bruxelles).

Moyer, H. Wayne \& Timothy E. Josling (1990), Agricultural Policy Reform: Policy and Process in the EC and USA (Harvester Wheatsheaf: Hemel Hempsted).

Noble, Joan (2012), Policy Scenarios for EU Sugar Market Reform, PE 495.823 (European Parliament: Brussels).

Swinbank, Alan (2015), 'The WTO: No longer relevant for CAP Reform?', in Johan Swinnen (ed.), The Political Economy of the 2014-2020 Common Agricultural Policy: An Imperfect Storm (Rowman \& Littlefield International: London), 193-213. 
Swinbank, Alan (2017), World Trade Rules and the Policy Options for British Agriculture post-Brexit, UK Trade Policy Observatory Briefing Paper 7 (University of Sussex: Falmer). www.sussex.ac.uk/webteam/ gateway/file.php? name=briefing-paper-7-final.pdf\&site $=18$.

Swinbank, Alan \& Carsten Daugbjerg (2006), 'The 2003 CAP reform: Accommodating WTO pressures', Comparative European Politics, 4(1): 47-64. doi.org/10.1057/palgrave.cep.6110069.

Swinbank, Alan \& Carolyn Tanner (1996), Farm Policy and Trade Conflict: The Uruguay Round and CAP Reform (The University of Michigan Press: Ann Arbor).

Tangermann, Stefan (2004), 'Agricultural policies in OECD countries ten years after the Uruguay Round: How much progress?', in Giovanni Anania, Mary E. Bohman, Colin A. Carter \& Alex F. McCalla (eds), Agricultural Policy Reform and the WTO: Where Are We Heading? (Edward Elgar: Cheltenham), 15-42.

Tanner, Carolyn (1996), 'Agricultural trade liberalisation and the Uruguay Round', Australian Journal of Agricultural Economics 40(1): 1-35. doi.org/10.1111/j.1467-8489.1996.tb00726.x.

WTO (World Trade Organization) (2008), Revised Draft Modalities for Agriculture, TN/AG/W/4/Rev.4 (WTO: Geneva).

WTO (2015), Export Competition. Ministerial Decision of 19 December 2015, WT/MIN(15)/45, WT/L/980, 21 December (WTO: Geneva). 
This text is taken from Australia, the European Union and the New Trade Agenda, edited by Annmarie Elijah, Don Kenyon, Karen Hussey and Pierre van der Eng, published 2017 by ANU Press, The Australian National University, Canberra, Australia. 